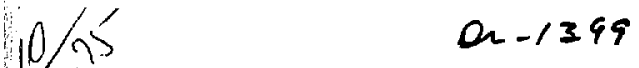

UCRL-51812

\title{
CHARACTERIZATION OF ASTM ROUND-ROBIN TUNGSTEN-POWDER SAMPLES
}

Charles A. Slettevold

Arthur H. Biermann

May 15, 1975

Prepared for U.S. Energy Research \& Development

Administration under contract No. W-7405-Eng-48

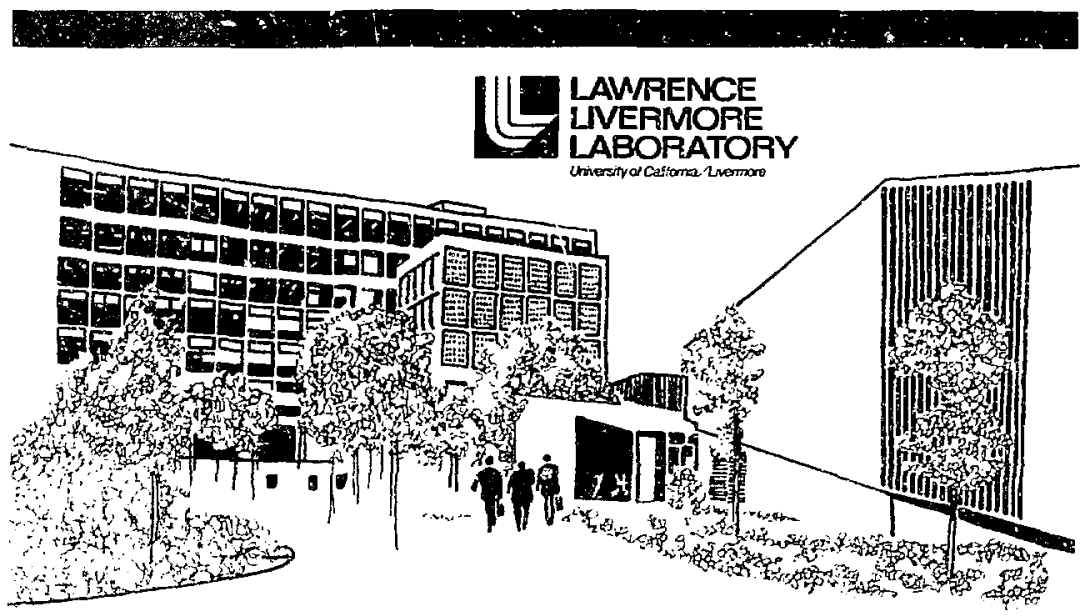


NOTIC:

"This report was prepared as an account of work sponsufed by the United States Givernment. Neither the United States not the United States Energy Research $\&$ Developmen' Administration, not any of their cmployees, not any of their contractors. subcontractors or their omployecs malies any subcontractors, of thesr employecs, malies iny liabjlity of responsitility for the reuracy, compieteness or usefulness of any information. apparatus, product or process viselosed, or represents that its we would not infringe privately-owned rights."

Printed in the United States of America Available from

National Technical Information Service

U. S. Department of Commerce 5285 Port Royal Road

Springfield, Virginia 22151

Price: Printed Copy $\$$ *; Microfiche $\$ 2.25$

$$
\begin{gathered}
\frac{\text { Pages }}{1-50} \\
51-150 \\
151-325 \\
326-500 \\
501-1000
\end{gathered}
$$

NTIS

Selling Price

$\$ 4.00$

$\$ 5.45$

$\$ 7.60$

$\$ 10.60$

$\$ 13.60$ 


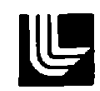

\title{
LAWRENCE INERMORE LAEOAATOFY

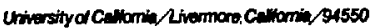

\section{UCRL -51812 \\ CHARACTERIZATION OF ASTM ROUND-ROBIN TUNGSTEN-POWDER SAMPLES}

\author{
Charles A. Slettevold \\ A rthur H. Biermann \\ MS. date: May 5, 1975
}

\begin{abstract}
This report was prepared as an account of wosk sponered by the Uniled Stutes Gomentent, Neithes the Unted States not the United Stata Energy Rexelch and Developnent Aderinistation, not any of thetr cmployces, not any of theis contractors, subcontractors. of thet employecs, make any warranty. expiess of fmplied. or astumes any leg thbility it tesnumability for the actiracy, comeletenes

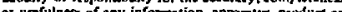

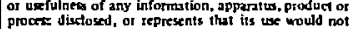
inftinge privately owned riphts.
\end{abstract}




\section{Contents}

Abstract

Int roduction

Types of Analysis and Equipment

Initial Sample Handling

Methods and Results

Micrographs

Apparent-, Tap-, and True-Density Determinations . . . . . . 2

Apparent Density

Tap Density

True Density

Surface-A rea Analysis

Average Size by the Fisher Sub-Sieve Method

Weight Distribution by Centrifugation

Weight Distribution by the Coulter Counter - - . . . . . . 6

Number Distribution by Light Microscopy and Image Analysis . . . . 6

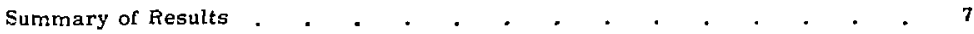

Ackrowledgments . . . . . . . . . . . . . . . . B

Appendix A. Lazy-Susan Sample Splitter . . . . . . . . . . . 9

Appendix B. Micrographs . . . . . . . . . . . . . 11

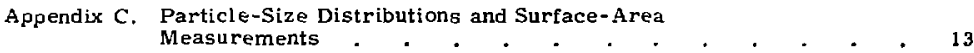




\title{
CHARACTERIZATION OF ASTM ROUND-ROBIN TUNGSTEN-POWDER SAMPLES
}

\begin{abstract}
The Lawrence Livermore Laboratory subcommittee included measurements (LLL) Particle Characterization Laboratory Group has participated in an industry-wide round-robin investigation aimed at the characterization of tungsten powder. The round-robin series is sponsored by the ASTM Subcommittee on Refractory-Metal Powders (B-09.3). The analyses performed at the suggestion of the ASTM of tap density, apparent density, true density, average particle size, and surface area. We also performed determinations of particle-weight and size distributions, and conducted particle inspection by microscopy. This report describes the equipment and procedures used and summarizes the results of these analyses.
\end{abstract}

\section{Introduction}

This report presents the results of tests performed by the Lawrence Livermore Laboratory (LLL) Particle Characterization Laboratory Group of the Chemistry and Materials Science Department on five samples of tungsten powder. These samples were supplied to LLL as part of the Laboratory's participation in an industry-wide round-robin effort aimed at the characterization of tungsten-metal powder. This effort is sponsored by the ASTM Subcommittee on Refractory-kietai Powders (B-09.3) as part of its efforit to develop a standard reference powder and to compare currently unstandardized techniques.

\section{Types of Analysis and Equipment}

The equipment us ed and types of analyses performed as part of our participation in this characterization study are listed in Table 1. Any variances from standard ASTM procedures are indicated in the discussions of methods and results.

\section{Initial Sample Handling}

The ASTM subcommittee sent LLL five tungsten-metal-powder samples which were numbered 196 through 200. These were the LLL portion of the sar ples sent 
Table 1. Equipment used for characterization.

\begin{tabular}{|c|c|}
\hline Type of analysin & Equipment \\
\hline Tap derudy & $\begin{array}{l}\text { Tap-l'ak Volumcler } \\
\text { J. Engctgmann A.G. } \\
\text { Aimkl JEL ST2 }\end{array}$ \\
\hline Apparest denfity & Carsey funnel \\
\hline True detisity & 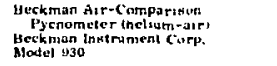 \\
\hline Surface oreu & 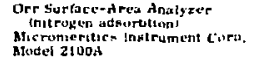 \\
\hline Arerage niz: & 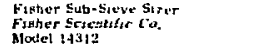 \\
\hline \multirow[t]{2}{*}{$\begin{array}{l}\text { lartele-wetght } \\
\text { distribution }\end{array}$} & 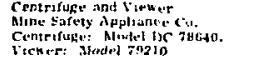 \\
\hline & 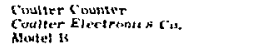 \\
\hline $\begin{array}{l}\text { Pa rucle-nu mber } \\
\text { distribution }\end{array}$ & 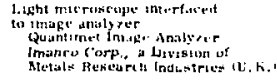 \\
\hline \multirow[t]{2}{*}{$\begin{array}{l}\text { Macrugraph } \\
\text { aralysis }\end{array}$} & 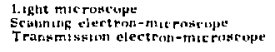 \\
\hline & 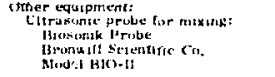 \\
\hline
\end{tabular}

Reference to a company ar priduct name bues mit imply appraval or recomntendation of the undart by the labversity of

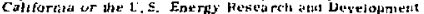

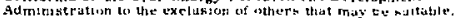

to all the participants in the roundrobin characterization effort. After receipt, the five samples were opened and quickly transferred into the entry port of a high-purity-argon glove-box line. The port was evacuated to less than $2.66 \mathrm{~Pa}$ pressure and back. rilled with an argon atmosphere containing less than one ppm of either oxygen or water vapor. This was done three times. All sampling and some of the analyses were performed in an argou-filled glove box. A "lasy-susan" sample splitter (dessribed in Appendix A), was used to separate samples for the various tests into the spproximate sizes needed. Beiore any tests were made in which moisture would be a factor, all samples were baked at $100^{\circ} \mathrm{C}$ in a vacturn oven for about 16 hours.

\section{Methods and Resuits}

\section{MICROGRA PHS}

Micrographs; of sample No. 196 were taken using a light microscope, a transmission electron-microscope, and a scanning electron-microscope. These are shown in Appendix B (Figs. B-1 through B-5). The presence of agglomerates in the samplc is apparent in these photographs. Cubical and other polygonal shapes of tungsten particles were encountered.

APPARENT-, TAP-, AND TRUEDENSITY DETERMINA TIONS

\section{Apparent Density}

Apparent density was measured by the Carney method in accordance with ASTM specitication B-417-64. Jiowever, in a previuss modification, our cup had une inch removed from its height, thereby reducing ats volume to less than half of the origitial.

Dried tungsten powder was placed in the Carney funnel. A cup of known weight and volume: was placed into a keyed position urifer the funnel and the ball swung away fror the stem. The powder flowed or was ajded in flowing until overflow. The lop of the cup was then scraped with a straightedge to remove excess material. The cup was tapped lightly to prevent loss of material in further hand?ing, and its weight was determined. This procedure was repeated three times and an average 
weight established from which the average apparent density was calculated. The results of the five samples are presented in Table 2 .

\section{Tap Density}

In accordance with ASTM specification 13-527-70, 50 grams of tungsten powder were added to a $25 \mathrm{ml}$ graduated cylinder, placed on a Tap-pak volumeter, and tapped 3000 times. The volume was read and the weight of tungsten determined.

Results of three tests made on each of the five samples are given in Table 3.

\section{Irue Density}

An air-comparison pycnometer was used to determine the true density of the powder samples. A $60-$ to $70-\mathrm{gram}$ sample of dried tungsten powder was

Table 2, Apparent densities.

\begin{tabular}{cccccc}
\hline Sample & $\begin{array}{c}\text { Weight No. L } \\
(\mathrm{g})\end{array}$ & $\begin{array}{c}\text { Weight No.2 } \\
(\mathrm{g})\end{array}$ & $\begin{array}{c}\text { Weight No.3 } \\
(\mathrm{g})\end{array}$ & $\begin{array}{c}\text { Average } \\
(\mathrm{g})\end{array}$ & $\begin{array}{c}\text { Apparent density } \\
\left(\mathrm{Mg} / \mathrm{m}^{3}\right)\end{array}$ \\
\hline 196 & 25.387 & 25.502 & 25.263 & 25.384 & 2.432 \\
197 & 25.138 & 25.066 & 24.978 & 25.061 & 2.401 \\
198 & 24.602 & 25.243 & 24.528 & 24.791 & 2.375 \\
190 & 25.581 & 25.818 & 25.520 & 25.640 & 2.456 \\
200 & 25.597 & 25.327 & 25.640 & 25.521 & 2.445 \\
& \multicolumn{5}{r}{ Average Apparent Lensity } \\
\hline
\end{tabular}

Table 3. Tap densities.

\begin{tabular}{|c|c|c|c|c|c|}
\hline $\begin{array}{c}\text { Sample } \\
\text { No. }\end{array}$ & $\begin{array}{c}\text { Irial } \\
\text { No. }\end{array}$ & $\begin{array}{l}\text { Weight } \\
\text { (g) }\end{array}$ & $\begin{array}{l}\text { Volume } \\
\text { (ml) }\end{array}$ & $\begin{array}{l}\text { Denssity } \\
\left(\mathrm{Mg}_{1} \mathbf{r n}^{3}\right)\end{array}$ & $\begin{array}{l}\text { Average density } \\
\text { for each sample } \\
\left(\mathrm{M}_{\mathrm{g}} / \mathrm{m}^{3}\right)\end{array}$ \\
\hline 196 & 1 & 50.0670 & 11.7 & 4.2792 & \\
\hline 196 & 2 & 49.8160 & 11.75 & 4.2396 & \\
\hline 196 & 3 & 50.0100 & 11.85 & 4.2202 & 4.25 \\
\hline 197 & 1 & 50.2074 & 11.8 & 4.2548 & \\
\hline 197 & 2 & 50.0352 & 11.75 & 4.2584 & \\
\hline 197 & 3 & 50.2362 & 11.8 & 4.2573 & 4.26 \\
\hline 198 & 1 & 49.110 & 11.65 & 4.2842 & \\
\hline 198 & 2 & 50.2775 & 11.7 & 4.2972 & \\
\hline 198 & 3 & 50.0501 & 11.65 & 4.2061 & 4.29 \\
\hline 199 & 1 & 50.1522 & 11.5 & 4.3610 & \\
\hline 159 & 2 & 50.0402 & 11.5 & 4.3513 & \\
\hline 199 & 3 & 49.6928 & 11.45 & 4.3399 & 4.35 \\
\hline 200 & 1 & 49.8490 & $11.6 \mathrm{~s}$ & 4.2788 & \\
\hline 200 & 2 & 50.1765 & $11.7 \overline{5}$ & 4.2703 & \\
\hline 200 & 3 & 50.1145 & 11.7 & 4.2832 & 4.28 \\
\hline & & \multicolumn{3}{|c|}{ Overall average density for the five samples } & 4.2847 \\
\hline
\end{tabular}


placed in the pycnometer cup and the volume measured three to four times. The sample was then weighed and a dense stainless steel ball of approximately the same volume as the sample was placed in the cup and measured. An appropriate correction factor was determined using the known volume of the ball. All five samples were tested. Results are tabulated in Table 4.

\section{SURFACE-AREA ANAL YSIS}

Twenty - to thirty-gram samples were used for the static (non-flowing) nitrogenadsorption surface-area determination. The samples were baked under vacuum for four hours at about $220^{\circ} \mathrm{C}$ prior to making the determinations.

B runauer-Emmett -Teller (BET) adsorption isotherms were generated using from 7 to 12 points of partial pressure. From the resulting slope and intercept, the surface area was calculated and the particle size of an average equivalent sphere was determined.

In Table 5, these values are shown for the five samples. A typical $B E T$ adsorption curve is given in Appendix $C$ (Fig. $C-I$ ).
Table 4. True densities.

\begin{tabular}{lccc}
\hline $\begin{array}{l}\text { Sample } \\
\text { No. }\end{array}$ & $\begin{array}{c}\text { Measured } \\
\text { volume } \\
(\mathrm{ml})\end{array}$ & $\begin{array}{c}\text { Weight } \\
(\mathrm{g})\end{array}$ & $\begin{array}{c}\text { Density } \\
\left(\mathrm{Mg} / \mathrm{m}^{3}\right)\end{array}$ \\
\hline 196 & 3.44 & 66.2827 & 19.27 \\
197 & 3.39 & 64.8605 & 19.13 \\
198 & 3.42 & 65.0680 & 19.32 \\
199 & 3.37 & 64.4785 & 19.13 \\
200 & 3.37 & 64.5120 & 19.14 \\
\multicolumn{2}{l}{ Average density of all tive lots } & 19.20 \\
\hline
\end{tabular}

\section{AVERAGE SIZE BY THE FISHER} SUB-SIEVE METHOD

Results of Fisher Sub-Sieve analysis for samples No, 197 and No. 200 are presented in Table 6 . The equipnient was calibrated with a sib-sieve calibrator Iserial number 11601 with the porosity sit at 0.75 . The high reading of 5.15 and low reading of 2.01 were accurate within the reading ability of the sizer.

\section{WEIGHT DISTRIBUTION H: CENTRIFUGATION}

The Whitby sedimentation method, which was used for these determinations, requires four centrifuges and a viewcr.

Table 5. Results of surface-arta analysis.

\begin{tabular}{llllll}
\hline $\begin{array}{c}\text { Sample } \\
\text { No. }\end{array}$ & Intercept & Slope & $\begin{array}{c}\text { Surface area } \\
\left(\mathrm{m}^{2} / \mathrm{g}\right)\end{array}$ & $\begin{array}{c}\text { Standard } \\
\text { deviation }\end{array}$ & $\begin{array}{c}\text { Calculated diameter } \\
(\mu \mathrm{m})\end{array}$ \\
\hline 196 & $0.09 \mathrm{~J}: 7$ & 7.0203 & 0.612 & 0.00175 & 0.51 \\
197 & $\mathbf{0 . 0 8 7 6 4 2}$ & 6.9913 & 0.615 & 0.00155 & 0.51 \\
198 & $\mathbf{0 . 0 9 0 1 1 1}$ & 7.0438 & 0.610 & 0.00122 & 0.51 \\
199 & $\mathbf{0 . 1 0 1 7 !}$ & $\mathbf{6 . 7 3 4 7}$ & $\mathbf{0 . 6 3 7}$ & 0.00280 & 0.49 \\
200 & $\mathbf{0 . 1 0 3 4 4}$ & $\mathbf{6 . 8 1 2 1}$ & $\mathbf{0 . 6 2 9}$ & 0.00451 & 0.50 \\
& Average surface area & $\mathbf{0 . 6 2 1}$ & & \\
\hline
\end{tabular}


Table 6, Fisher sub-sieve average particle size.

\begin{tabular}{ccc}
\hline Sample & Porosity & $\begin{array}{c}\text { Average diameter } \\
(\mu \mathrm{m})\end{array}$ \\
\hline 197 & 0.80 & 1.43 \\
200 & 0.80 & 1.43 \\
\hline
\end{tabular}

See Fig. 1. The centrifuge tubes, which are of is special design, have a $0.7 \mathrm{~mm}$ capillary at the bottom of each.

The samples were first split to near the needed size for the analysis using the LLL lazy-susan sample splitter (see Fig. A-1). In this anaiysis we used the Mine Safety Appliance (MSA) sample scoop, which is designed to give a proper-sized sample. The narrow size distribution of the samples made it necessary to use a lower conceatration of powder than would have bein necessary for more heterogeneous samples. This is due to the narrow time range within which a majority of the particles fall, thereby causing a highconcentration zone in the sedimentation liquid. This tended tc lead to reagglomeration and a biasing of data to the upper sixes.

The sedimentation fluid used in this analysis consisted of water containing $0.1 \%$ Daxad No. 23 as a dispersant. The samples were prepared by dispersing the powder in $1 \mathrm{ml}$ of a feeder liquid consisting of $70 \%$ sedimentation fluir and $30 \%$ acetont. The suspension was first ultrasonically mixed using a small tip on a Biosonic probe and then stirred on a vortex mixer until ready for use. The

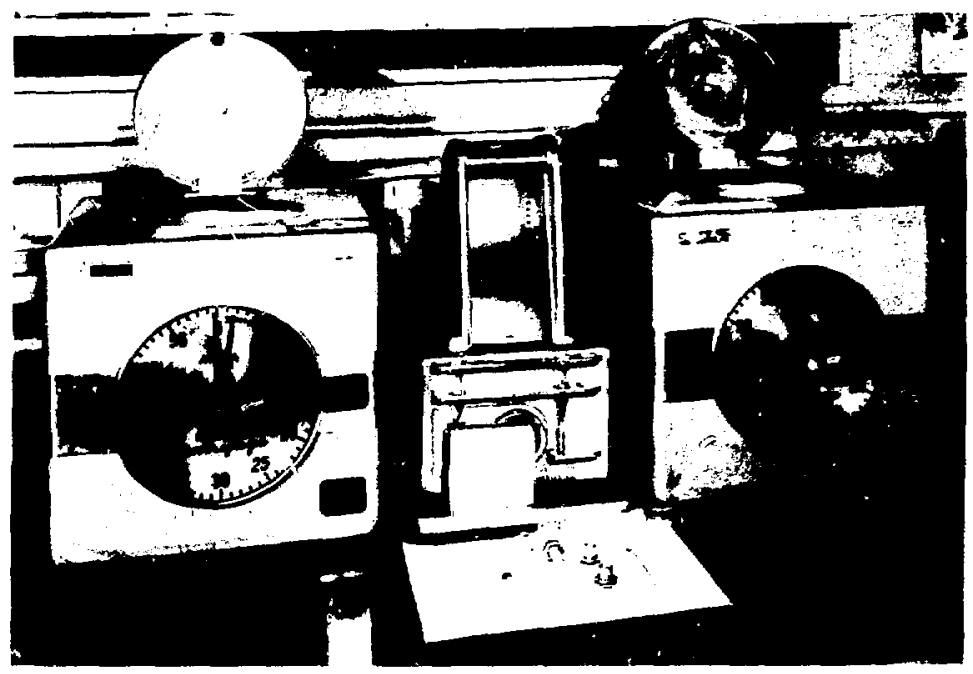

Fig. 1. Centrifugal sedimentation equipment for determination of particle-weight distribution. 
sample was placed in the feeder chamber and hand mixed until it was layered out on the surface of $10 \mathrm{ml}$ of sedimentation fluid contained in the centrifuge tube.

According to a predetermined schedule of times and centrifuge speeds, the height of the puwder sediment in the capillary of the centrifuge tube was measured on the viewer. Each sedimentation time corresponded to a certain Stoke's diameter based on an assumed spherical particle. A minimum of two trials per sample vere made. Further samples were run until agreement of results was reached. A computer plot of the cumulative weight distribution and a weight-distribution histogram are shown in Appendix $C$ for sample No. 196. A summary of the distributions for samples 196 to 200 is given in Table 7.

\section{WEIGHT DISTRIBUTION RY THE COULTER COUNTER}

A Coulter Counter with a $50 \mu \mathrm{m}$ aperture was used for determination of particle-weight distribution. In preparation for analysis, the samples were rubbed in electrolyte (1\% isoton) on a small watch glass. The dispersed powder was then added to a beaker containing more electrolyte and ultrasonically mixed using a sonic prabe. To keep the larger particles and aggregates suspended, stirring was maintained th roughout th $t_{i}$ counting period. Total counts for the various samples ranged between 2,000 and 14,000 particles. The 20th, 50th, and 80 th percentiles of the cumulative-weight percentage below stated size are listed in Table B. Appendix C (Figs $\mathbf{C}-2$ through $\mathbf{C}-9$ ) gives examples of computer-generated output showing cumulative percent by weight
Table 7. Particle diameters corresponding to the 20th, 50th, ind solt percentiles of the weight distribution as determined by centrifugal sedimentation.

\begin{tabular}{|c|c|c|c|}
\hline \multirow[b]{2}{*}{$\begin{array}{c}\text { Sample } \\
\text { No. }\end{array}$} & \multicolumn{3}{|c|}{ Maximum particle dianeter } \\
\hline & $\begin{array}{c}\text { Lower } \\
20 \% \\
\text { by } \\
\text { weight }\end{array}$ & $\begin{array}{c}\text { Lower } \\
50^{\circ} \\
\text { by } \\
\text { wcight }\end{array}$ & $\begin{array}{l}\text { l.ower } \\
\text { 30\% } \\
\text { by } \\
\text { weight }\end{array}$ \\
\hline 196 & 3.3 & 5.7 & 8.5 \\
\hline 197 & 3.3 & 5.2 & 4.0 \\
\hline 198 & 2.1 & 3.4 & 4.7 \\
\hline 199 & 2.3 & 3.5 & 5.0 \\
\hline 200 & 4.8 & 6. I & 10.8 \\
\hline
\end{tabular}

Table 8. Particle diameters corresponding to the 20th, 50th, ard Boti: pereentiles of the weight distribution as determined by Coulter-Countor analysis.

\begin{tabular}{|c|c|c|c|}
\hline \multirow[b]{2}{*}{$\begin{array}{l}\text { Sample } \\
\text { No. }\end{array}$} & \multicolumn{3}{|c|}{$\begin{array}{l}\text { Maximum particle diameter } \\
(\mu \mathrm{m}) \text { for indicated percentile }\end{array}$} \\
\hline & $\begin{array}{c}\text { Lower } \\
20 \% \\
\text { by } \\
\text { weight }\end{array}$ & $\begin{array}{c}\text { Lower } \\
50 \% \\
\text { by } \\
\text { weight }\end{array}$ & $\begin{array}{c}\text { J.ower } \\
80 \% \\
\text { by } \\
\text { weight }\end{array}$ \\
\hline 196 & 2.5 & 3.8 & 5.8 \\
\hline 197 & 2.d & 4.0 & 6.0 \\
\hline 198 & 2.8 & 4.2 & 8.5 \\
\hline 199 & 2.8 & 3.7 & 10.0 \\
\hline 200 & 3.6 & 4.5 & 5.9 \\
\hline
\end{tabular}

below stated size and weight-distribution histograms for samples 196 and 199.

NUMBER DISTRIBUTION BY LIGHT MICROSCOPY AND IMAGE ANALYSIS

The LLL particle-characterization facility employs an image-analysis system (Fig. 2) for determination of particle-size distributions. This system 


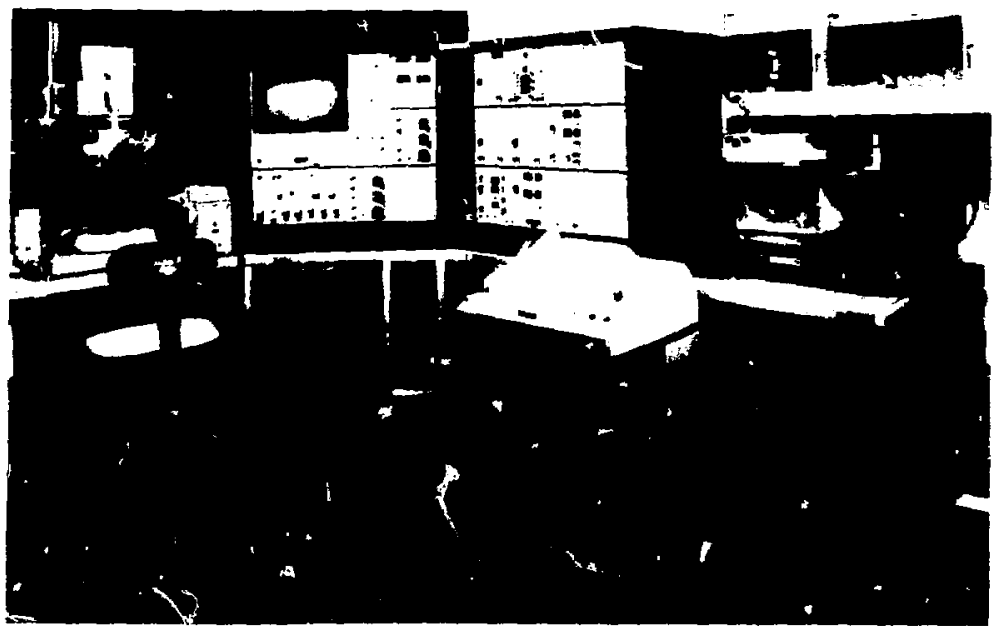

Fig. 2, Image analysis facility.

an he interfsced to a light microscune with all itutomatle stage-advance, a scanning - lectron-microscope, or an epidiascope fru wituation of pictures ne negatives.

fur sica determination of the five l.hl. rium-rubu thapten sumples the light

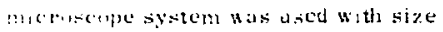

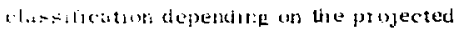
aria no the tungsten panducles. First, lunpster samples wero dispersed in jmmrrion vil on sliries by means of a $2-\mathrm{mm}$ ditum worlen dowel. Fach slide was then pliced on the microserope stage and a mignification was chosen. Hetwen 1400 inal 3000 particlu's wore counted and sized for fiach sample. The counting of many agglomerates was eliminated by using the pattern-recognition feature of the image analyzer. Computer results of the image ansiysis anclude plots of percent number versus equisalent spherical diameter, and a colculated weight virsus equivalent spherical diametr. A cubical shape-fact or was used in the calculations. Plot: include both cumulative percert below stated size and histogram distributions. Table ? lists summary cumulative percent data foc the five samples. Typical computer output is included in Appendix $C$. In Table s, note that because of variation between samples some anal;ses were repeated.

\section{Summary of Results}

- The average apparent, tap, and true densities of the five round-robin tungsten samples Xos. 146 to 200 , were 2.423 , 4.285 , and $19.2 \mathrm{Mg}, \mathrm{m}^{\prime}$, respectively. The 
Table 9. Particle diameters corresponding to 20th, 50th, and 80 th percentiles for the cumulative number and weight distribution as determined by image analysis.

\begin{tabular}{|c|c|c|c|c|c|c|c|}
\hline \multirow[b]{2}{*}{$\begin{array}{c}\text { Sample } \\
\text { No. }\end{array}$} & \multicolumn{6}{|c|}{ Maximum particle diameter $(\mu \mathrm{m})$ for indicated percentile } & \multirow[b]{2}{*}{ Bagnification $(X)$} \\
\hline & $\begin{array}{c}\text { Lower } \\
20 \% \\
\text { by number } \\
\text { (irequency) }\end{array}$ & $\begin{array}{c}\text { Lower } \\
50 \% \\
\text { by number } \\
\text { (Irequency) }\end{array}$ & $\begin{array}{c}\text { Lower } \\
80 \% \\
\text { by number } \\
\text { (frequency) }\end{array}$ & $\begin{array}{c}\text { l.ower } \\
20 \% \\
\text { by weight } \\
\text { \{calculated\} }\end{array}$ & $\begin{array}{c}\text { Lowar } \\
50 \% \\
\text { by weight } \\
\text { \{calculated }\end{array}$ & $\begin{array}{c}\text { Lower } \\
80 \% \\
\text { by weight } \\
\text { (calculated) }\end{array}$ & \\
\hline 196 & 1.3 & 2.3 & 3,8 & 4.0 & 7.0 & 9.5 & 500 \\
\hline 196 & 1.4 & 2.3 & 3.9 & 3.4 & 5.0 & 0.5 & 312.5 \\
\hline 196 & 0.9 & 1.6 & 2,6 & 2.5 & 3.6 & 0.0 & 500 \\
\hline 197 & 1.0 & 1.7 & 2.0 & 2.5 & 3.5 & 4.7 & 500 \\
\hline 197 & 1.0 & 1.6 & 2.6 & 2.3 & 3.2 & 4.4 & $\hat{\mathbf{s}} 00$ \\
\hline 398 & 1.2 & 2.3 & 3,8 & 3.6 & 6.0 & 15.0 & 500 \\
\hline 199 & 1.7 & 2.7 & 4.7 & 3.8 & 5.8 & 8.5 & 312.5 \\
\hline 200 & 1.3 & 2.1 & 3.9 & 3.3 & 4.5 & 5.8 & 312.5 \\
\hline
\end{tabular}

average surface a rea determined by nitrogen adsorption was $0.621 \mathrm{~m}^{2} / \mathrm{g}$. These particle-characterization measurements varied little in the five samples tested.

- Larger variations were encountered in measuring the particle size distributions using the centrifugal-sedimentation, Coulter-Counter, and microscope-image analysis. The variations in size distributions may be caused by nonrepresentative sampling since very small sample amounts are required for these analyses. Size variations can also be attributed to the large number of aggregates present, as shown by the micrographs.
- The particie diameters by microscopeimage analysis corresponding to the 50th percentile by number ranged from 1.6 to $2.7 \mu \mathrm{m}$. Weight distributions from microscope-image analysis, as calculated from number distributions, were in the range of sizes determined from direct weight-distribution measurements.

- The spread of particle diameters corresponding to the 50th percentile by weight, were 3.2 to $5.0 \mu \mathrm{m}$ by microscope-image analysis: 3.7 to $7.2 \mu \mathrm{m}$ by centrifugal sedimentation; and 3.7 to $4.5 \mu \mathrm{m}$ by use of the Coulter Counter.

\section{Acknowledgments}

The authors' gratitude is extended to Roy O. Lindahl and Carol M. Weaver fo: their work in the particle characterization of these samples. 


\section{Appendix A}

\section{Lazy-Susan Sample Splitter}

The LLL lazy-susan sample splitter (Fig. $A-1$ ) has been developed to divide a powder sample into small but representative fractions of the original. The device, consisting of an eight-inch pan housing eight pie-shaped pans, is mounter on a variable speed rotating table. Extending upward through the eight-inch pan is a rod which provides stationary support for a lucite cover, a vibrator, a feeder trough, and a funnel.

The rate of flow of the powder, which is related to such factors as shape, particle size, static charge, and moisture, can be regulated by the vibration and clearance between the funnel tip and the feed trough. The rotation rate determines the quality of the separation. 


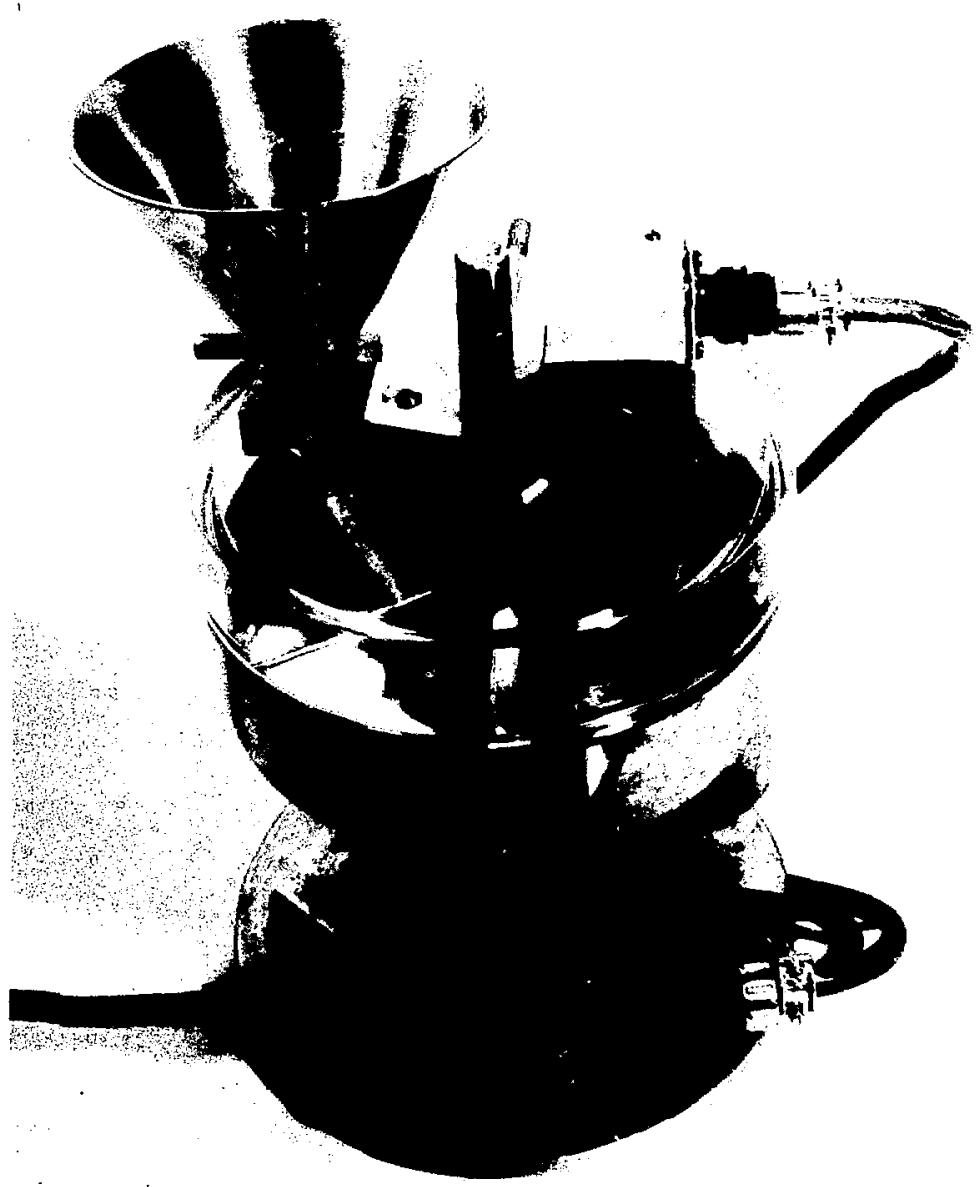

Fig. A-1. LLL Lazy-susan sample splitter, 


\section{Appendix B}

\section{Micrographs}

Eigures B-1 through B-5 are photographs of sample No, 196 as viewed by (a) light microscopy, (b) transmission electron microscopy, and (e) scanning el ectron microscopy.

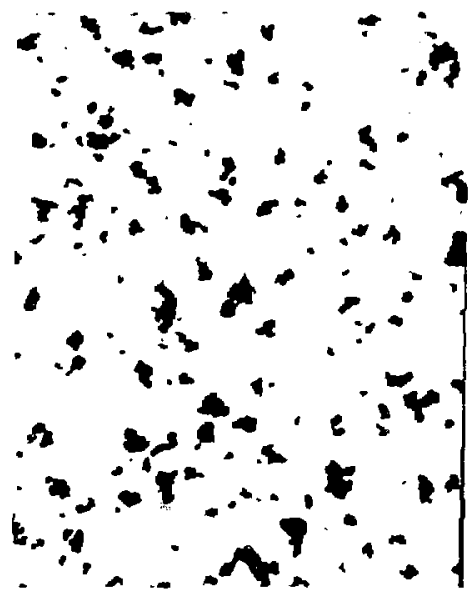

Fig. B-1. Sample 196 yiewed by light microscopy (820X).

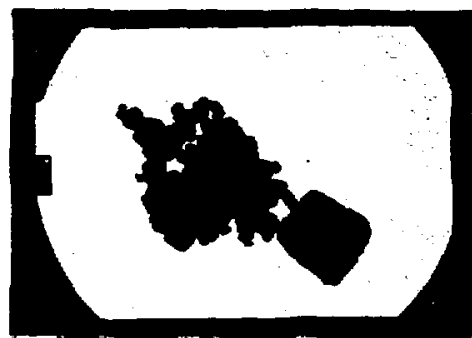

Fig. B-2, Sample 196 viewed by transmission electron microscope (1250x).

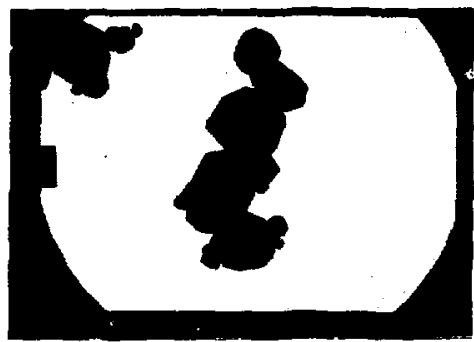

Fig. B-3, Sample 196 viewed by transmission electron microscope $\langle 12,500 \times\}$. 


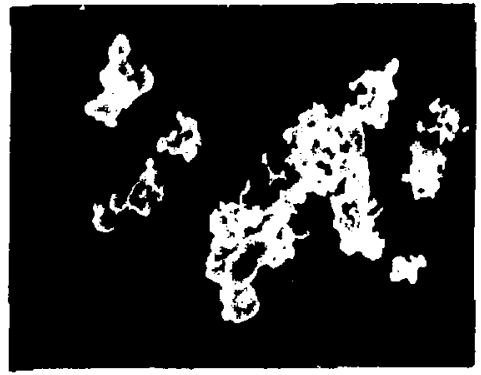

Fig. B-4. Sample 196 viewed by scanning electron microscope $(2000 \times)$.

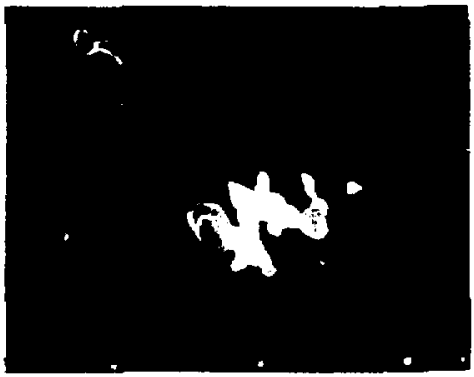

Fig. B-5. Sample 196 viewed by scanning electron microscope (2000). 


\section{Appendix C}

\section{Particle-Size Distributions and Surface-Area Measurements}

Figures $\mathrm{C}-1$ through $\mathrm{C}-9$ are computergenerated diagrams showing selected particle-size distributions resulting from surface-area analysis, centrifugalsedimentation analysis, Coulter-Counter measurements, and microscopy-image analysis.
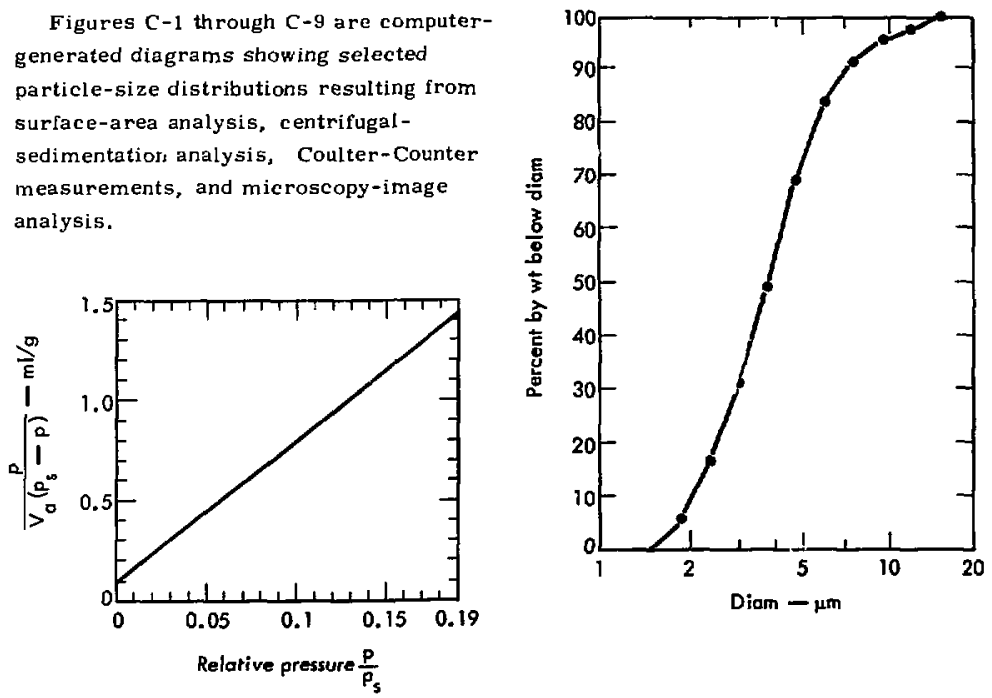

Fig. C-1. Sample 196. BET isotherm from surface-area analysis, where $\mathrm{p}=$ partial pressure of gas; $p_{s}=$ saturation pres sure of gas; and $v_{a}=$ volume of adsorbed gas.

Fig. C-2, Sample 196. Cumulative weight distribution by CoulterCounter analysis. 


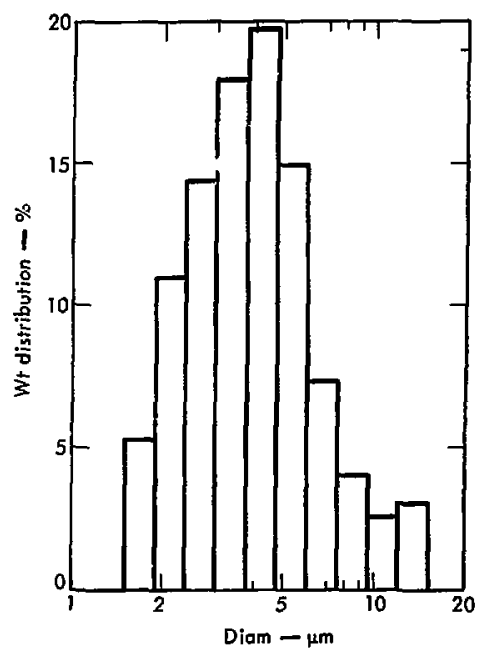

Fig. C-3. Sample 196. Weight distribution by Coulter-Counter analysis.

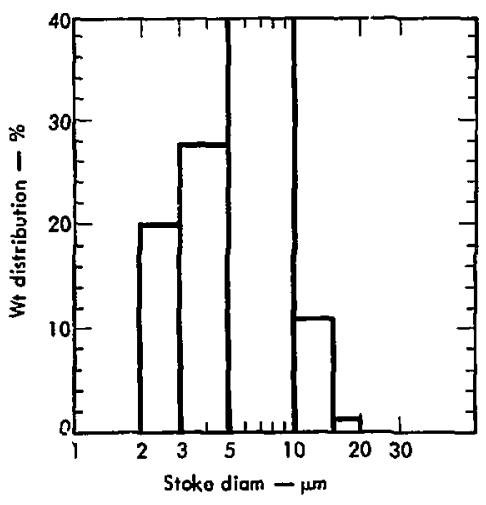

Fig. C-5. Sample 196. Weight distribuit . . by centrifugal sedimentat.on.

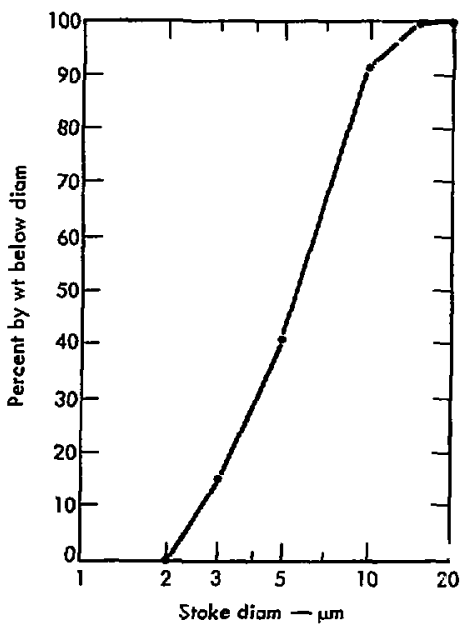

Fig. C-4. Sample 196. Cumulative weight distribution by centrif ugal sedimentatiun.

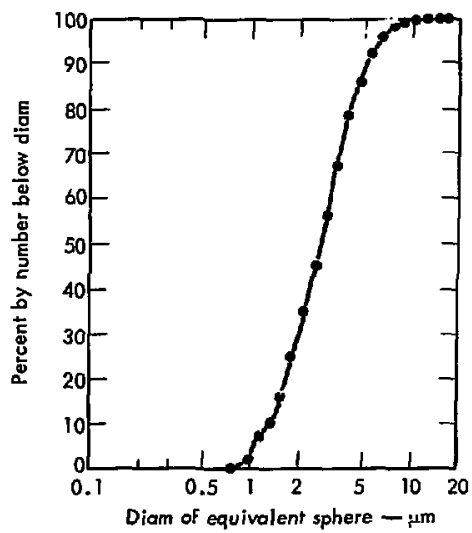

Fig. C-6. Sample 199. Cumulative size distribution by number, from image analysis using light microscopy. 


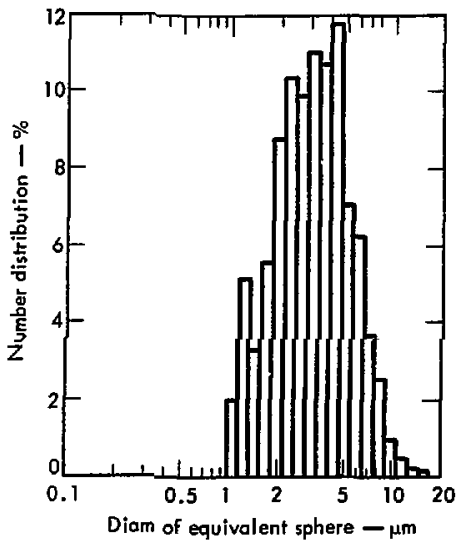

Fig. C-7. Sample 199. Number distribution by image analysis using light microscopy.

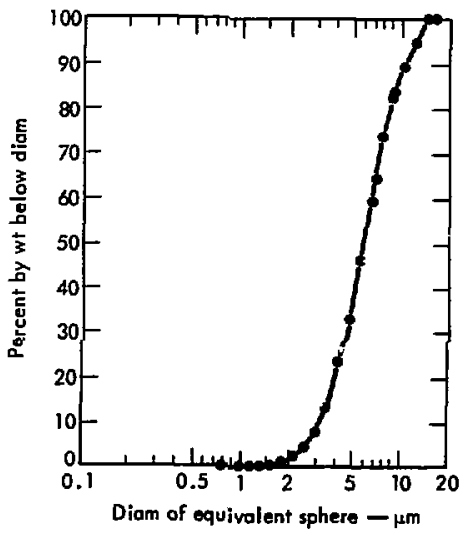

Fig. C-8. Sample 199. Cumulative weight distribution as calculated from the number distribution from image analysis using light misroscopy).

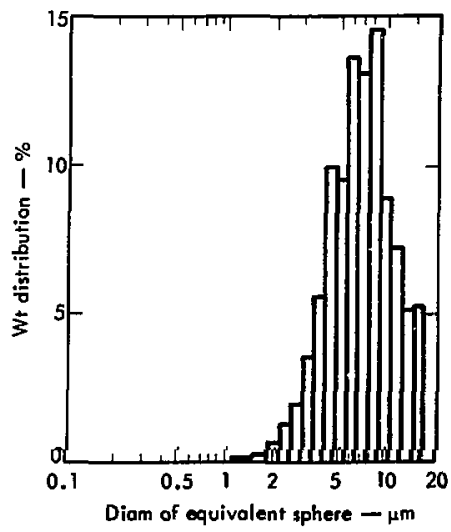

Fig. C-9, Sample 199, Height distribution as calculated from the number distribution (fron) $\mathrm{IMM} / \mathrm{lc} / \mathrm{la}$ image analysis using light microscopy). 